\title{
Geri Çekilen Makaleler ve Yayımlandıkları Dergiler Üzerine Bibliyometrik İnceleme
}

\section{Bibliometric Examination of Retracted Articles and Journals in Which They Were Published}

\author{
Tuğba Güngör* ve Nimet Başarı **
}

$\ddot{\mathrm{O} z}$

Amaç: Bilimin bütünlüğünü korumak için kusurlu çalışmalara uygulanan en önemli mekanizma makalelerin geri çekilmesidir. Çeşitli sebeplerden dolayı geri çekilen makalelerin sayısındaki artış dikkat çekmektedir. Bu çalışmada, bilimsel bilgiye zarar veren bu makalelerdeki parametreleri keşfetmek amaçlanmıştır. Yöntem: Araştırmada, Web of Science (WoS)'da geri çekilmenin en fazla olduğu ilk 100 dergi seçilmiştir. Seçilen bu dergilerden 1978-2020 yılları arasında 1934 makalenin geri çekildiği saptanmıştır. Çalışma kapsamında yanıt aranan sorular şunlardır: 1. Geri çekilen makale sayısının en fazla olduğu yıl veya yıllar hangisidir? 2. Geri çekilen makale sayısı hangi dergi çeyreğinde daha fazladır? 3. Geri çekilen makalelerde konu dă̆ılımı nasıldır? 4. Geri çekilen makale sayısı hangi ülke/ülkelerde daha fazladır? 5. Makalelerin yayımlandıkları ve geri çekildikleri yıl arasındaki zaman farkı ne kadardır? Bulgular: Inceleme sonucunda makalelerin geri çekilme oranlarının yıllar geçtikçe artış gösterdiği saptanmıştır. Makalelerin çoğu $(\% 19,5)$ yayımlandıktan bir yıl sonra geri çekilmiştir. Makalelerde en çok geri çekilme, Q1 çeyreğindeki dergilerde olmuştur. Makalelerin konu dă̆llımında ise "Oncology" (\%17,2) ve "Biochemistry and Molecular Biology” (\%16,9) alanları öne çıkmıştır. Nature, Science ve Journal of Biological Chemistry dergilerinde yayımlanan makalelerin atıf oranı \%9'dur. Ülke sıralamasında ilk sırada yer alan Amerika Birleşik Devletleri (ABD), aynı zamanda en çok atıf (\%54) alan ülke olmuştur. Özgünlük: Konuya ilişkin, literatürde Türkiye adresli yayın saylsının az olduğu bilinmektedir. Bu doğrultuda geri çekilen makalelerin mevcut durumu ve değişimleri incelenmiştir. Sonuç: Bilim etiğini ihlal eden geri çekilmiş makaleler, bilimsel iletişim sistemi içerisindeki tüm katılımcıların farklı açılardan değerlendirilmesini sağlamıştır. Çeşitli değişkenler çerçevesinde incelenmiş bu yayınların sonuçları, konuyla ilgili daha fazla yayın yapılması ve çözüm geliştirilmesi gerektiğini göstermiştir.

Anahtar Sözcükler: Geri çekilen makaleler; bibliyometri; dergi çeyrekleri; dergi etki faktörü; WoS.

\footnotetext{
* Hacettepe Üniversitesi, Bilgi ve Belge Yönetimi Bölümü. E-posta: gngrtuba7@gmail.com Hacettepe University, Department of Information Management, Turkey

** Hacettepe Üniversitesi Bilgi ve Belge Yönetimi Bölümü, nimet.basari95@gmail.com Hacettepe University, Department of Information Management, Turkey
}

Geliş Tarihi - Received: 24.08.2020

Kabul Tarihi - Accepted: 19.02.2021 


\begin{abstract}
Objective: The most important mechanism applied to flawed studies to protect the integrity of science is the retraction of articles. The increase in the number of articles which have been retracted for various reasons is remarkable. Therefore, it is aimed to discover the parameters in these articles that harm scientific knowledge. Method: In the research, the first 100 journals with the highest number of retracted articles in Web of Science (WoS) were selected. Between 1978 and 2020, 1934 articles were retracted from the selected journals. This study sought to answer the questions: 1. In which years has the highest number of retracted articles been? 2. Which journal quartiles have the highest number of retracted articles? 3. What is the distribution of topics in retracted articles? 4. Which countries have more retracted articles? 5. What is the time difference between the year in which articles are published and retracted? Results: According to the review result, the rate of retracted articles has increased over the years. The articles were retracted one year after publication have a percentage of $19.5 \%$. The number of retracted articles was in Q1-quartile journals is the highest. In the subject distribution of these retracted articles, "Oncology" (17.2\%) and "Biochemistry and Molecular Biology" (16.9\%) were prominent. The citation rate for retracted articles published in the journal Nature, Science and Journal of Biological Chemistry is 9\%. The United States (USA), which ranked first in the country rankings of the retracted articles, receives the most citations with 54\%. Originality: In the literature, it is found that there are limited number of Turkey originated publications about the topic. In this direction, existing state and changes of the retracted articles were examined. Conclusion: Retracted articles that violate science ethics have enabled all participants in the scientific communication system to be evaluated from different points of view. The results of these publications, which were examined within the framework of various variables, showed that more publications on the subject should be made and solutions should be developed.
\end{abstract}

Keywords: Retracted articles; bibliometry; journal quartile; journal impact factor; WoS.

\title{
Giriș
}

Akademik yayın sayısındaki artış, bilimsel bilginin çeşitlenmesini sağlarken yanlış, çalıntı ya da suistimal edilmiş bilginin de ortaya çıkmasına neden olmaktadır. Bu olumsuz durumun önüne geçmek için etik kurullar, bilimsel yayınlarda düzeltme ya da geri çekme işlemleri uygulamaktadırlar. Yayın Etiği Komitesi (COPE) (2019) geri çekmeyi "literatürü düzeltmek, bulguları ve sonuçları güvenilmeyecek veya literatürde yer alamayacak kusurlu veriler içeren makaleleri uyarmak için bir mekanizma" şeklinde tanımlamıştır. Akademik çalışmaların geri çekilmesi, niteliksiz bilginin bilimsel topluluktan temizlenmesini sağlar (Ajiferuke ve Adekannbi, 2020, s. 169). Geri çekme ya da düzeltme işlemi özellikle dijital teknolojilerin ve veri tabanlarının (Science Direct, PubMed, Scopus, Scielo, vb.) ortaya çıkmasıyla ve literatürün daha görünür hale gelmesiyle ilişkilendirilmektedir (Gutiérrez ve diğerleri, 2016, s. 569). Araştırmalarda yapılan suistimaller, bilimin standartlarını ihlal etmekle birlikte, bütünlüğü bozmakta, araştırmalarda kamu güvensizliği oluşturmakta ve projelerin geliştirilmesi için olumsuz bir ortam yaratmaktadır (Hermerén, 2008, s. 10). Makalelerin geri çekilmesi, bilimsel literatürün bütünlüğünü korumak için bilim camiasının kendi kendini düzeltme mekanizmasıdır (Chen, Hu, Milbank ve Schultz, 2012, s. 234). Geri çekme işlemlerinin temel amacı, yanlış 
davranan yazarları cezalandırmak yerine literatürü düzeltmek ve bütünlüğünü sağlamaktır (Wager, Barbour, Yentis ve Kleinert, 2009, s. 202).

Bilim etiği açısından önemli bir yere sahip olan geri çekilen makalelerle ilgili literatürde pek çok çalışma vardır. Fakat yapılan Türkçe literatür taramasında konuya ilişkin çalışmalar oldukça yetersiz bulunmuştur. Geri çekilen makalelerle ilgili Türkiye adresli az sayıda yayın bulunmaktadır (Al ve Soydal, 2015; Alrawadieh ve Zareer, 2019). Bu çalışmada geri çekilmiş makaleler farklı analiz birimleri üzerinden değerlendirilerek, makalelerin bilimsel literatüre etkilerini araştırmak amaçlanmıştır. WoS 'tan erişilen geri çekilen makalelerin yayımlandığı dergilerin, alanlara göre dağılımına ve geri çekilme süresine ilişkin inceleme yapılmıştır. Buna ek olarak dergilerin hangi çeyrekte yer aldığı bilgisi ve geri çekilmiş makalelerin konuya göre farklılıklarının nedenleri araştırılarak değerlendirmelerin sonuçları sunulmuştur.

\section{Önceki Çalışmalar}

Yayınların geri çekilmesine yönelik araştırmalarda temel konular; yayınların neden geri çekildiği, dergilerin yayınları geri çekme politikaları ya da geri çekilen yayınlar ile dergi etki faktörü arasındaki ilişki olmuştur. Damineni, Sardiwal, Waghle ve Dakshyani (2015, s. 20), makalelerin geri çekilme nedenlerini araştırdıkları çalışmada; hata, intihal, duplikasyon, uydurma veriler ve etik konular gibi çeşitli nedenlerden geri çekildiği bilgisine erişmişlerdir. $\mathrm{Bu}$ nedenlerin yanı sıra hiçbir sebep olmadan geri çekilen makalelerin de olduğu aktarılmıştır. Bir diğer çalışmada ise en yaygın geri çekme nedenlerinin bilimsel sahtekârlık ve suistimaller olduğu ifade edilmiştir (Fang, Steen ve Casadevall, 2012, s. 17028).

Dergilerde geri çekilme işlemi farklılık göstermektedir. Yüksek etki faktörü değerine sahip bir dergide yayımlanan bir makalenin geri çekilme olasılığının, düşük etki faktörü değerine sahip dergide yayımlanan bir makaleye göre daha yüksek olduğu ifade edilmektedir (Fang ve Casadevall, 2011, s. 3856). Dergi etki faktörü ile geri çekilme arasındaki ilişkiyi açıklamak amacıyla biyomedikal bilim dalında, geri çekilmiş makalesi bulunan dergiler üzerine yapılan çalışmada, 611 farklı dergide makalelerin geri çekildiği saptanmıştır. Bu makalelerin yayımlandığı dergilerin çeyrek dağılımına bakıldığında, makalelerin \%51,4'ü yüksek etki faktörü değerine sahip dergilerde, \%33,1'i düşük etki faktörü değerine sahip dergilerde ve \%15,5'i etki faktörü değeri hesaplanmayan dergilerde yer aldığı sonucuna ulaşılmıştır (CamposVarela, Villaverde-Castañeda ve Ruano-Raviña, 2020, s. 2). Fanelli (2013, s. 3-4), WoS'taki geri çekilme sayısında son 20 yılda artış olduğunu tespit etmiştir. Çalışmada, veri tabanındaki dergilerde yapılan düzeltme işlemindeki oranın arttığı belirtilmektedir. Dergilerde gerçekleşen geri çekme işleminin kronolojik analizi sonucunda, son y1llarda sadece Proceedings of the National Academy of Sciences of the United States of America (PNAS) geri çekilmelerde artış göstermektedir. Nature ve Science dergilerinde 2002-2003 yılları dışında büyük bir artış saptanmamıştır. Yapılan araştırmalarda, geri çekilen makalelerin yüksek etki faktörüne sahip dergilerde yer aldığı ortaya konulmuştur. Etki faktörü değeri düşük olan veya etki faktörü hesaplanmayan dergilerin de makalelerin geri çekilmesine neden olan davranışlardan kaçınmadığı anlaşılmıştır. Ancak, bu alt sıradaki dergilerin akran denetimine daha az maruz kalıp kalmadığının tartışmalı olduğu belirtilmektedir (Foo, 2010, s. 460). Biyomedikal ve yaşam bilimleri alanında yapılan bir çalışmada, New England Journal of Medicine, Nature ve Science gibi ünlü dergilerin geri çekilme sayılarının yüksek olduğu ifade edilmiştir (Foo, 2010, 
s. 463). Aynı alanda yapılan farklı bir çalışmada PubMed'den elde edilen verilerde, geri çekilen yayınların ülkelere göre dağılımında ABD, Almanya, Japonya ve Çin'in farklı kategorilerde (bilimsel sahtekârlık, kopyalama, intihal) üst sıralarda yer aldığı görülmüştür (Fang ve diğerleri, 2012, s. 17029).

Araştırmalarda düşük gelirli ülkelerde, yayınların geri çekilme sayısının daha fazla olduğu tartışma konusudur. Stretton ve diğerleri (2012, s. 1575), hem düşük gelirli hem de anadili İngilizce olmayan ülkelerde intihal nedeniyle geri çekilme riskinin diğer ülkelere göre daha yüksek olduğunu belirtmişlerdir. Ancak genel oranlar değerlendirilerek ülkeler arasında bir karşılaştırma yapılmamıştır. Ülkeler üzerine yapılan başka bir değerlendirme de ise, ABD'nin geri çekilmeye en yatkın ülke olarak ilk sırada yer aldığı tespit edilmiştir. Ayrıca bu araştırmada Çin'in intihal ve duplikasyon nedeniyle geri çekilen makale sayısında en yüksek sayıya sahip olduğu da görülmektedir (Amos, 2014, s. 89).

Makalelerin yayımlanma ve geri çekilme sürelerinin araştırıldığı bir çalışmada geri çekilme süresinin ortalama 32,91 ay olduğu tespit edilmiştir. Geri çekilme süreleri iki farklı zaman periyodunda incelenmiştir. İlk periyotta 1973 ve 2002 yıllarını kapsayan 714 geri çekilmiş makale incelenmiş ve ortalama geri çekilme süresi 49,82 ay olarak saptanmıştır. İkinci periyotta 2003 ve 2012 yıllarını kapsayan 1333 makalenin ortalama geri çekilme süresinin 23,82 aya düştüğü gözlemlenmiştir. Makalelerin geçmişe göre daha hızlı geri çekildiği belirtilmiştir (Steen, Casadevall ve Fang, 2013, s. 4).

Atıf ile geri çekme işlemi arasındaki ilişki araştırmalara konu olmuştur. Buna yönelik literatürde çeşitli çalışmalar bulunmaktadır. Al ve Soydal (2015, s. 31-32) atıf ile geri çekilme ilişkisini araştırdığı çalışmalarında, üç atıf türünü ele almışlardır. Bu türler; makalenin yayımlandığ1 yıl ile geri çekme notunun paylaşıldığı zaman arasındaki atıflar, geri çekme notunun yayımlandığı yıl içinde yapılan atıflar ve geri çekme notu yayımlandıktan sonra yapılan atıflardır. İncelemeye alınan atıflar içerisinde makalelerin yayımlandıkları yıl ve geri çekildikleri yıl arasında aldıkları atıf oranın \%55 olduğu tespit edilmiştir. Geri çekilen makalelere yapılan atıfların \%15'i makalenin geri çekildiği yıl içerisinde gerçekleşirken, \%30'u ise makaleler geri çekildikten sonra yapılmıştır. Değerlendirmeler sonucu makalelerin geri çekildikten sonra da atıf almaya devam ettiği saptanmıştır. Geri çekilen makalelere yönelik farklı bir çalışmada ise atıfların sistematik bir incelemesi gerçekleştirilmiştir. PubMed, Scopus ve Retraction Watch'tan elde edilen verilerde geri çekme sonrası alıntılarda belirgin bir düşüş olduğu ve bu alıntıların çoğunun, geri çekilen makalenin yayınlandığı ülkeden farklı ülkelerden geldiği tespit edilmiştir (Dinh ve diğerleri, 2019, s. 390).

\section{Amaç ve Yöntem}

Bu araştırmada, WoS'ta geri çekilmenin en fazla olduğu ilk 100 dergi seçilmiştir. 1978-2020 arasında 1416 dergiden toplamda 5182 makale geri çekilmiştir. Dergiler geri çekilen makale sayısına göre en yüksekten en düşüğe göre sıralandığında geri çekilen makalelerin \%38'i $(\mathrm{n}=5182) \quad$ ilk 100 dergide $(\mathrm{n}=1416)$ yayımlanmıştır. Araştırmamız kapsamında değerlendirmeye alınan ilk 100 dergi evreni temsil etmemektedir. Bu doğrultuda makalelerin ülke ve konu dağılımını saptamak, dergi çeyreklerini ve etki faktörünü incelemek, geri çekilmeye ilişkin tarihsel gelişimi değerlendirmek hedeflenmiştir. Çalışmanın temel hipotezi 
"Dergi etki faktörü ile makalelerin geri çekilme süresi arasında ilişki vardır." şeklinde belirlenmiştir. Araştırma kapsamında aşağıdaki sorulara yanıt aranmıştır:

- Geri çekilen makale sayısının en fazla olduğu yıl veya yıllar hangisidir?

- Makalelerin yayımlandıkları ve geri çekildikleri yıl arasındaki zaman farkı ne kadardır?

- Geri çekilen makale sayısı hangi dergi çeyreğinde daha fazladır?

- Geri çekilen makalelerde konu dağılımı nasıldır?

- Geri çekilen makale sayısı hangi ülke/ülkelerde daha fazladır?

Araştırmanın yöntemi ve tekniği konusunda bilgiler verilerin toplanması başlığı altında detaylı bir şekilde aktarılmıştır.

\section{Verilerin Toplanması}

Araştırmanın verileri WoS atıf veri tabanından elde edilmiştir. Veri tabanında dizinlenen geri çekilmiş makaleleri saptamak amacıyla 10 Mart 2020 tarihinde söz konusu kaynaktan tarama yapılmıştır. WoS üzerinden geri çekilen makalelere erişmek için "Başlık" alanına "Retracted Article" yazılarak işlem gerçekleştirilmiştir. Bu aşamada çeşitli sınırlamalar yapılmıştır. Öncelikle "Doküman Türü” bölümünden "Makale” seçeneği seçilmiş ve ek olarak "Kaynak Başlıkları" alanındaki ilk 100 dergi belirlenerek daraltma işlemi uygulanmıştır. Geri çekilen makaleleri tanımlamak için orijinal başlığın sonundaki parantez içerisinde "Retracted Article" ifadesi yer alan makaleler inceleme kapsamına dahil edilmiştir (bkz. Şekil 1). Tarama sonucunda yayın türü makale olan ve 1978-2020 yılları arasında yayımlanmış 1934 çalışmaya ulaşılmıştır. İndirilen veri dosyasında bulunan başlık ve dergi verileri temel alınarak dergilerin çeyreği bilgisine erişilmiştir. Makalenin yayımlandığı dergi çeyreğine ve etki faktörüne erişmek için WoS'ta bulunan Journal Citation Reports veri tabanından yararlanılmıştır. Başlık içerisindeki "Quartile in Category" WoS'ta tanımlanan sınıfları ifade etmektedir. Veri tabanı bu kategorileri “Q1, Q2, Q3, Q4” şeklinde sınıflandırmaktadır. Çeyrek dilimlerde Q1 ilk çeyrekte (ilk \%25'lik bölümde), Q2 ikinci çeyrekte (\%25-\%50), Q3 üçüncü çeyrekte (\%50-\%75), Q4 dördüncü çeyrekte (en alt \%25) yer alan dergiler olarak değerlendirilmektedir. Bazı dergilerin iki farklı kategoride sınıflandığı tespit edilmiştir. Örneğin; Transplantation dergisi hem Q1 hem de Q2 çeyreğinde yer almaktadır. Aynı derginin aynı yıl içindeki iki farklı değeri olduğu durumlarda, literatürdeki benzer çalışmada da (Pajić, 2015, s. 993) yapıldığı üzere daha büyük olan dergi çeyreği dikkate alınmıştır. Veriler WoS'ta belirtilen 2018 yılını temel almaktadır. Veri toplama sürecinde bazı dergilerin $W o S$ 'tan çıkarıldığı saptanmıştır. Veri tabanında dergi çeyreklerine ve etki faktörüne ilişkin bilgilerin yer almamasından dolayı bu makaleler veri kümesinden çıkarılmıştır.

\section{RETRACTED: ANXIETY DISORDERS IN DEVELOPMENTAL AGE (Retracted Article)}

\section{By: Maltese, Agata; Cerroni, Francesco; Romano, Palmira; et al.}

\section{ACTA MEDICA MEDITERRANEA Volume: 34 Issue: 4 Pages: 937-943 Published: 2018}

\section{Şekil 1. WoS geri çekilme bilgisi}

Araştırma kapsamındaki bir diğer analiz dosyası makalelerin geri çekildikleri yıl ile yayımlandıkları yılları içermektedir. Excel dokümanında yer alan bilgiler WoS'tan indirilen veri seti içerisinden alınmıştır. Bu aşamada makale başlığında yer alan parantez içerisindeki yıl 
bilgileri geri çekilme yılı olarak tanımlanmıştır (bkz. Şekil 2). Bazı makalelerde bu bilgiler yer almamaktadır. Yapılan analizin doğru sonuçlanması için bu veriler dosyadan çıkarılmıştır.

RETRACTED: Noninvasive Evaluation of GPR119 Agonist Effects on beta-Cell Mass in Diabetic Male Mice Using In-111-Exendin-4 SPECT/CT (Retracted article. See vol. 161, 2020)

This publication has been retracted by the following retraction

Notice of retraction: Noninvasive Evaluation of GPR119 Agonist Effects on beta-Cell Mass in Diabetic Male Mice Using In-111-Exendin-4 SPECT/CT (Retraction of Vol 160, Pg 2959, 2019)

Şekil 2. WoS’ta geri çekilme yılı bilgisi olmayan makale örneği

Analiz dokümanlarına yönelik veri düzenleme ve çıkarma işlemi tamamlandıktan sonra görselleştirme için sosyal ağ analizi programı olan CiteSpace ve bilimsel haritalama programı VosViewer kullanılmıştır. Verilerin konusal dağılımına bakılabilmesi için ".xlsx" formatında olan dosya CiteSpace'in tanımladığı “.txt” formatına dönüştürülmüştür. Programın arayüzünde bulunan yeşil renkli alanda "Term", "Keyword", "Category" seçenekleri bulunmaktadır. Yayınlarda geçen terimleri, anahtar kelimeleri ve konu kategorilerini incelemek için bu alanlar kullanılmaktadır. Konu dağılımıyla ilgili veriyi elde edebilmek için "Category" seçeneği seçilerek, "Time Slicing” bölümünden yıl sınırlaması yapılmıştır. İşlem sonucu elde edilen görsel Tree-ring History ${ }^{1}$ yöntemi ile sunulmuştur. Çalışmada incelenen bir diğer nokta ülke dağılımlarıdır. İstenilen bilgiye erişebilmek için daha önce CiteSpace'te tanımlanan ".txt" formatı VosViewer programına aktarılmıştır. Arayüzün sol bölümünde bulunan "Map" alanından yeni harita oluşturulmuştur. Ekrana çıkan ilk kutucukta "Create a map based on bibliographic data" işaretlenerek veri türü seçilmiştir. Bir sonraki işlemde veri kaynağ belirlenerek tanımlanan dosya aktarılmıştır. Son aşamada ise haritanın oluşturulması için analiz türünde "Co-authorship", analiz biriminde "Countries" ve toplam bağlantı gücünün, bağlantı sayısından büyük olması nedeniyle "Full counting" alanları işaretlenmiştir.

Analiz için kullanılan başka bir program da SPSS 21 olmuştur. Hipoteze konu olan dergi etki faktörü ve geri çekilme süresini içeren verilere ayrı ayrı istatistiksel testler uygulanmıştır. $\mathrm{Bu}$ değişkenlerin verilerinin normal dağılım göstermemesi sebebiyle Spearman-Korelasyon testi uygulanmıştır.

\section{Bulgular ve Yorum}

\section{Geri Çekilen Makalelerin Yıllara Göre Dağılımı ve Geri Çekilme Süreleri}

WoS veri tabanı tarafından dizinlenen ve geri çekilen makale sayısının en yüksek olduğu ilk 100 dergiden elde edilen verilere göre, 1989-2020 yılları arasında 1878 makalenin geri çekildiği saptanmıştır. Şekil 3'te gösterildiği üzere yıllar geçtikçe geri çekilen makale sayısında artış olduğu görülmüştür. $\mathrm{Bu}$ artış rahatsız edici olsa da yayınların düzeltilmesi ve hatalı araştırmaların daha hızlı tespit edilmesi açısından büyük önem taşımaktadır. Fakat bu geri çekilme sayıları okuyucuların bilimsel bilgiye olan güvenini azaltabilir. Buna ek olarak artış, akademik rekabetin ortaya çıkmasıyla ve araştırmacıların yayın çıkarma zorunluluğuyla da açıklanabilir.

\footnotetext{
1 “Tree-ring History”, bir makalenin atıf ağacı halkaları ile atıf tarihi arasındaki ilişkiyi gösteren yöntemdir.
} 


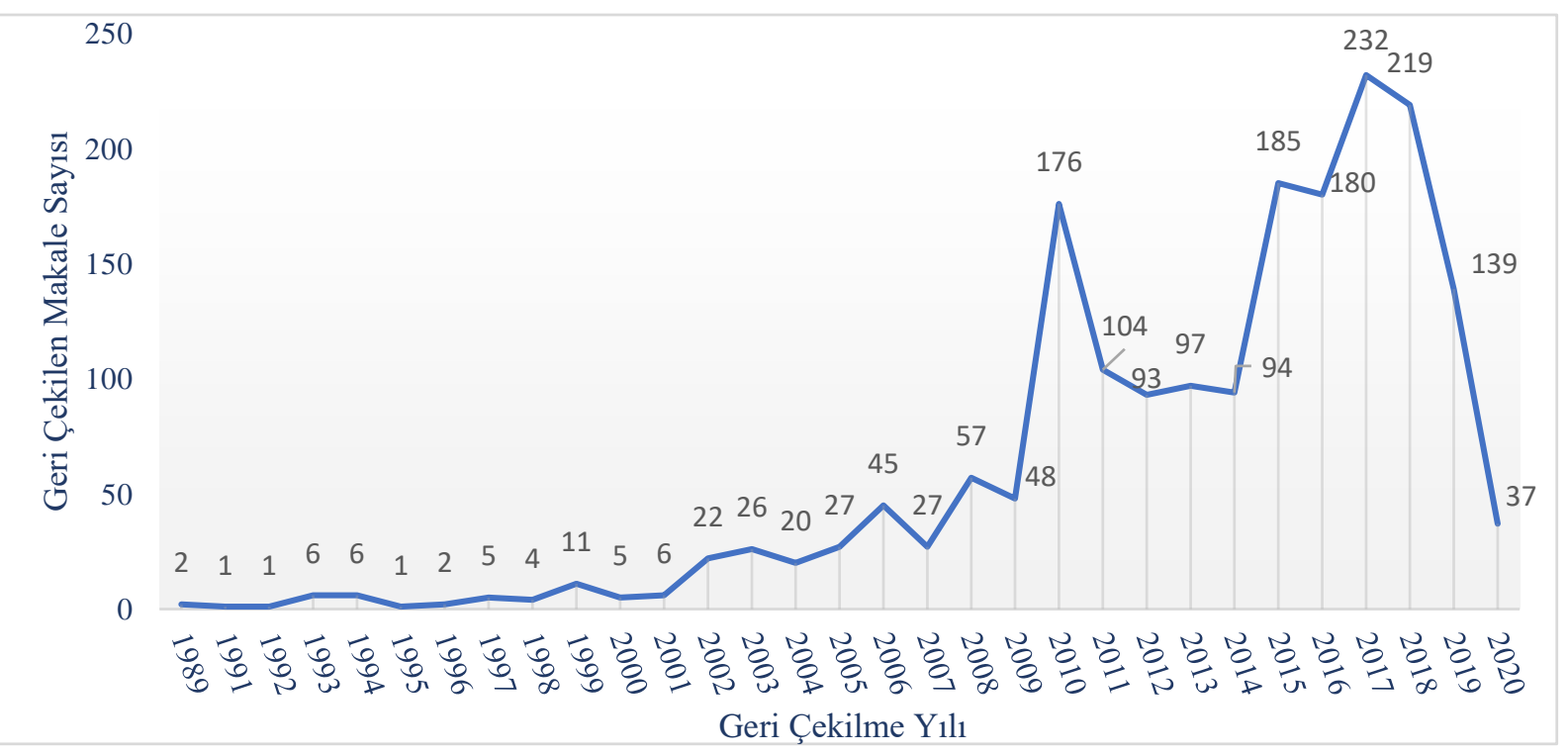

Şekil 3. Geri çekilen makalelerin yıllara göre dağılımı

2009 yılına kadar olan süreçte geri çekilen makale sayısının belli bir seyirde ilerlediği görülmektedir. 1989-2009 yılları aralığındaki makalelerin geri çekilme oranı \%17'dir. Bununla birlikte belirli dönemlerde geri çekilen makale sayısında artışlar olduğu gözlemlenmiştir. 2010 yılında makalelerin geri çekilme sayısı büyük bir ivme kazanmıştır (\%9). 2010 yılındaki geri çekilen makale, 4 ardışık (2007-2010) yıldaki toplam geri çekilen makalenin \%38'ni kapsamaktadır. Belirli bir yıldaki geri çekilme sayısındaki artış, bu ardışık yıldaki literatür büyümesi ile açıklanabilir. 2010-2020 yılları arasında geri çekilen makale sayısı ortalaması 152 ' dir $^{2}$. 2011 ve 2014 yılları arasında geri çekilme sayısında düşüş olduğu gözlemlenmiştir. Belirtilen y1l aralığında ortalama geri çekilme oranı \%20'dir. Makalelerin geri çekilme sayısında 2015-2018 yılları arasında artış olduğu görülmüştür. Bu yıl aralığında geri çekilen makale sayısı en fazla 2017 yılındadır (\%12). Bu durum son yıllarda yayın sayısındaki artış ve erişim kolaylığ 1 ile ilişkilendirilebilir. Şekildeki dikkat çeken diğer nokta da 2020 yılındaki geri çekilen makale sayısının az olmasıdır. Elde edilen sonucun, araştırma verilerine 2020 yılı Mart ayında erişilmesi ve yılın bitmemesi ile bağlantılı olduğu düşünülmektedir.

Araştırmada önemli bir başka konu makalelerin geri çekildikleri ve yayımlandıkları yıl arasındaki zaman farkıdır. Makalelerin geri çekilme notunda yer alan yıldan, yayımlandıkları yıl çıkarılarak zaman farkı hesaplanmıştır. Çalışmada bu işlem sürecinde 39 adet makalenin geri çekilme yılı bilgisine erişilememiştir. Bu nedenle 1878 makale üzerinden değerlendirme yapılmıştır (bkz. Tablo 1). Analiz sonucunda makaleler en fazla $(\% 19,5)$ yayımlandıktan bir yıl sonra geri çekilmiştir. Tablo 1'e bakıldığında makalelerin \%8,1'i yayımlandı̆̆ 1 yıl geri çekilmektedir. Makalelerin \%70'inin yayımlandıktan beş yıl sonra geri çekildiği görülmektedir. Benzer bir çalışmada da ortalama geri çekilme süresinin 5 yıl olduğu saptanmıştır. Bu sürenin, COPE' un yönergesinde yer alan "yanıltıcı yayınların zararlı etkilerini en aza indirmek için geri çekilme bildirimlerinin derhal yayınlanması gerektiği” ifadesine aykırı olduğu açıklanmaktadır (Wang, Ku, Alotaibi ve Rutka, 2017, s. 812).

\footnotetext{
${ }^{2} 2020$ yılında geri çekilen makale sayısı ilk 3 ayı içermektedir. Bu durumun ortalamayı düşürmesi nedeniyle 2020 yılı, geri çekilen makale sayısı ortalaması hesaplamasına dahil edilmemiştir.
} 
Tablo 1

Makalelerin yayımlandıkları yıl ve geri çekildikleri yıl arasındaki fark

\begin{tabular}{lrrr}
\hline & \multicolumn{3}{c}{ Geri çekilen makale } \\
\cline { 2 - 4 } Geri çekilme süresi (y1l) & $\mathrm{n}$ & $\%$ & Birikimli yüzde \\
\hline 0 & 152 & 8,1 & 8,1 \\
1 & 367 & 19,5 & 27,6 \\
2 & 278 & 14,8 & 42,4 \\
3 & 255 & 13,6 & 56,0 \\
4 & 146 & 7,8 & 63,8 \\
5 & 116 & 6,2 & 70,0 \\
6 & 88 & 4,7 & 74,7 \\
7 & 68 & 3,6 & 78,3 \\
8 & 71 & 3,8 & 82,1 \\
9 & 58 & 3,1 & 85,2 \\
10 ve daha fazla & 279 & 14,8 & 87,5 \\
\hline Toplam & 1878 & 100,0 & 100,0 \\
\hline
\end{tabular}

Tabloda 10 yıldan daha fazla sürede geri çekilmiş makaleler \%14,8'lik bir dilim oluşturmaktadır. Araştırmamızda 27 yıl sonra geri çekilmiş makale bulunmaktadır. Bu süre makalelerin konu alanları ve geri çekilme nedenleri ile ilişkilendirildiğinde ciddi problemler doğurabilir. Literatürde yer alan başka araştırmada 2002 yılında ve öncesinde yayımlanan geri çekilmiş makalenin ortalama geri çekilme süresi 4 yıl iken; 2002'den sonra yayımlanan geri çekilmiş makalenin ortalama geri çekilme süresinin 2 yıla gerilediği belirtilmiştir (Steen ve diğerleri, 2013, s. 4). Bu çalışmada olduğu gibi araştırmamızda elde ettiğimiz veriler sonucu geri çekilme süresinin son yıllarda düştügü görülmüştür. 2009 yılı ve öncesinde yayımlanan makalelerin ortalama geri çekilme süresi 9 yıl iken, 2010 yılı ve sonraki yıllarda yayımlanan makalelerin geri çekilme süresinin 8 yıla gerilediği saptanmıştır.

\section{Geri Çekilen Makalelerin Dergi Çeyrekliklerine Göre Dağılımı}

Geri çekilen makalelerin yayımlandığı dergilerin çeyrek dilim dağılımı incelenmiştir. 1878 makalenin yayımlandığı dergi çeyreğine ilişkin bulgular Tablo 2'de gösterilmektedir. En fazla geri çekilen makalenin yayımlandığı dergilerin \%45'i Q1 çeyreğinde yer almaktadır. Q1 çeyrek diliminde yer alan dergilerde yayımlanan 845 makale içinden en fazla geri çekme işlemi PNAS adlı dergide gerçekleşmiştir. PNAS, 66 makale $(\% 7,8)$ ile ilk sırada yer almaktadır. Derginin çalışma alanı incelendiğinde çok disiplinli bilimi kapsadığı görülmüştür. Buna ek olarak yüksek etki faktörü değerine sahip Cancer Research ve Nature dergilerinde geri çekilme oran $1 \% 3$ iken Science dergisinde $\% 2$ 'dir.

\section{Tablo 2}

Geri çekilen makalelerin dergi çeyreğine göre dă̆ıllımı

\begin{tabular}{lrr}
\hline Dergi Çeyreği & $\mathrm{n}$ & $\%$ \\
\hline Q1 & 845 & 45,0 \\
Q2 & 720 & 38,3 \\
Q3 & 114 & 6,1 \\
Q4 & 199 & 10,6 \\
\hline Toplam & 1878 & 100,0 \\
\hline
\end{tabular}


Q2 dergi çeyreğinde bulunan 720 makaleden (\%38,3) 142 'si (\%19,7), onkoloji dergisi olan Tumor Biology'den geri çekilmiştir. Devamında ise aynı çeyrekte yer alan Journal of Biological Chemistry $(\% 19,4)$, PLOS ONE $(\% 8,7)$ ve Journal of Immunology $(\% 4,5)$ dergileri ilk sıralarda yer almaktadırlar. Q4 dergi çeyreğinde de en fazla geri çekilme işlemi 199 makale $(\% 10,6)$ içinden 79 makale $(\% 39,6)$ ile kristallografi dergisi olan Acta Crystallographica Section E-Structure Reports Online adlı dergide gerçekleştirilmiştir. En az geri çekilmenin ise 114 makale $(\% 6,1)$ ile Q3 dergi çeyreğinde olduğu gözlemlenmektedir. 114 makaleden en fazla geri çekme işlemini yapan Molecular Biology Reports dergisi, 30 makale $(\% 26,3)$ geri çekmiştir. Derginin çalışma alanı biyokimya ve moleküler biyoloji üzerinedir. Belirtilen dergilerde yayımlanan makalelerin ortalama atıf sayısına bakılmıştır. En çok atıf alan makaleler \%3'lük oranla (2374 atıf) The New England Journal of Medicine adl1 dergide yayımlanmaktadır. PNAS dergisinde makalelerin ortalama atıf sayısı 67 iken, Tumor Biology dergisinde 12'dir. Acta Crystallographica Section E-Structure Reports Online (2) ve Molecular Biology Reports (4) dergilerinde yayımlanan makalelerin ortalama atıf sayısı diğer çeyrek dilimde yer alan dergilere göre düşüktür.

En fazla geri çekilmiş makalenin yayımlandığı ilk 10 dergi Tablo 3'te gösterilmiştir. Ön sıralarda yer alan bu dergilerin saygın ve popüler dergiler olduğu görülmektedir. Aynı zamanda yayın sayısı yüksek dergiler olması geri çekilme işleminin uygulanma olasılı̆̆ını da yükseltmektedir. Bu dergilerin konu alanı tıp, biyoloji ve çok disiplinli bilimleri içermektedir.

Tablo 3

Geri çekilen makale sayısının en fazla olduğu ilk 10 dergi ve konu alanları

\begin{tabular}{|c|c|c|c|c|}
\hline \multirow[t]{2}{*}{ Dergi Adı } & \multirow{2}{*}{$\begin{array}{l}\text { Dergi } \\
\text { Ceyreği }\end{array}$} & \multirow[t]{2}{*}{ Konu } & \multicolumn{2}{|c|}{ Geri çekilmiş makale } \\
\hline & & & $\mathrm{n}$ & $\%$ \\
\hline Tumor Biology & Q2 & Onkoloji & 142 & 7,5 \\
\hline Journal of Biological Chemistry & Q2 & $\begin{array}{l}\text { Biyokimya ve } \\
\text { moleküler biyoloji }\end{array}$ & 140 & 7,4 \\
\hline $\begin{array}{l}\text { Acta Crystallographica Section E-Structure Reports } \\
\text { Online }\end{array}$ & Q4 & Kristallografi & 79 & 4,2 \\
\hline $\begin{array}{l}\text { Proceedings of the National Academy of Sciences of } \\
\text { the United States of America }\end{array}$ & Q1 & Çok disiplinli bilim & 66 & 3,5 \\
\hline PLOS ONE & Q2 & Çok disiplinli bilim & 63 & 3,3 \\
\hline Cancer Research & Q1 & Onkoloji & 58 & 3,1 \\
\hline Nature & Q1 & Çok disiplinli bilim & 55 & 2,9 \\
\hline Science & Q1 & Çok disiplinli bilim & 45 & 2,1 \\
\hline Journal of Immunology & Q2 & İmmünoloji & 34 & 1,8 \\
\hline $\begin{array}{l}\text { Acta Crystallographica Section E-Crystallographic } \\
\text { Communications }\end{array}$ & Q4 & Kristallografi & 33 & 1,7 \\
\hline
\end{tabular}

Geri çekilen makale sayısının en yüksek olduğu dergi Q2 çeyreğinde yer almaktadır. Onkoloji konu alanında yer alan Tumor Biology dergisinde, geri çekilme sayısının yüksek olması alanın güncelliği ile ilişkilendirilebilir. Q4 dergi çeyreğinde olan ve kristallografi konu alanını kapsayan; geri çekilme sayısının en az olduğu dergi Acta Crystallographica Section ECrystallographic Communications'dır. En fazla geri çekilen makalelerin yer aldığı ilk on dergide ortalama geri çekilme sayısı 79'dur. Nature, Science ve Journal of Biological Chemistry dergilerinde yayımlanan makalelerin atıf oran $1 \% 9$ 'dur. Bu dergiler ilk on dergi içerisinde en yüksek atıf oranına sahiptir. 


\section{Dergi Etki Faktörü ve Makalenin Geri Çekilme Süresi Arasındaki İlişki}

Dergi etki faktörü ve geri çekilme yılı arasında istatistiksel açıdan anlamlı bir ilişki olup olmadığı araştırılmıştır. Spearman's Korelasyon testi sonucunda iki değişken arasında istatiksel açıdan anlamlı bir ilişki olduğu görülmektedir $(p<0,01)$. Değişkenler arasında pozitif yönlü ve zayıf düzeyde korelasyon bulunmaktadır (Spearman's $\mathrm{R}=0,158, \mathrm{p}=0,00$ ). Etki faktörü yüksek olan dergilerin \%25'inde geri çekilme süresinin kısa olduğu tespit edilmiştir. Geri kalan \%75'i için ise geri çekilme süresini etkileyen başka nedenler olduğu söylenebilir. Şekil 4'te gösterildiği üzere etki faktörü yüksek olan dergilerde, geri çekilme süresi 0-5 yıl aralığında yoğunlaşmıştır. $\mathrm{Bu}$ durum dergilerin makaleleri daha kısa sürede geri çektiği şeklinde yorumlanabilir.

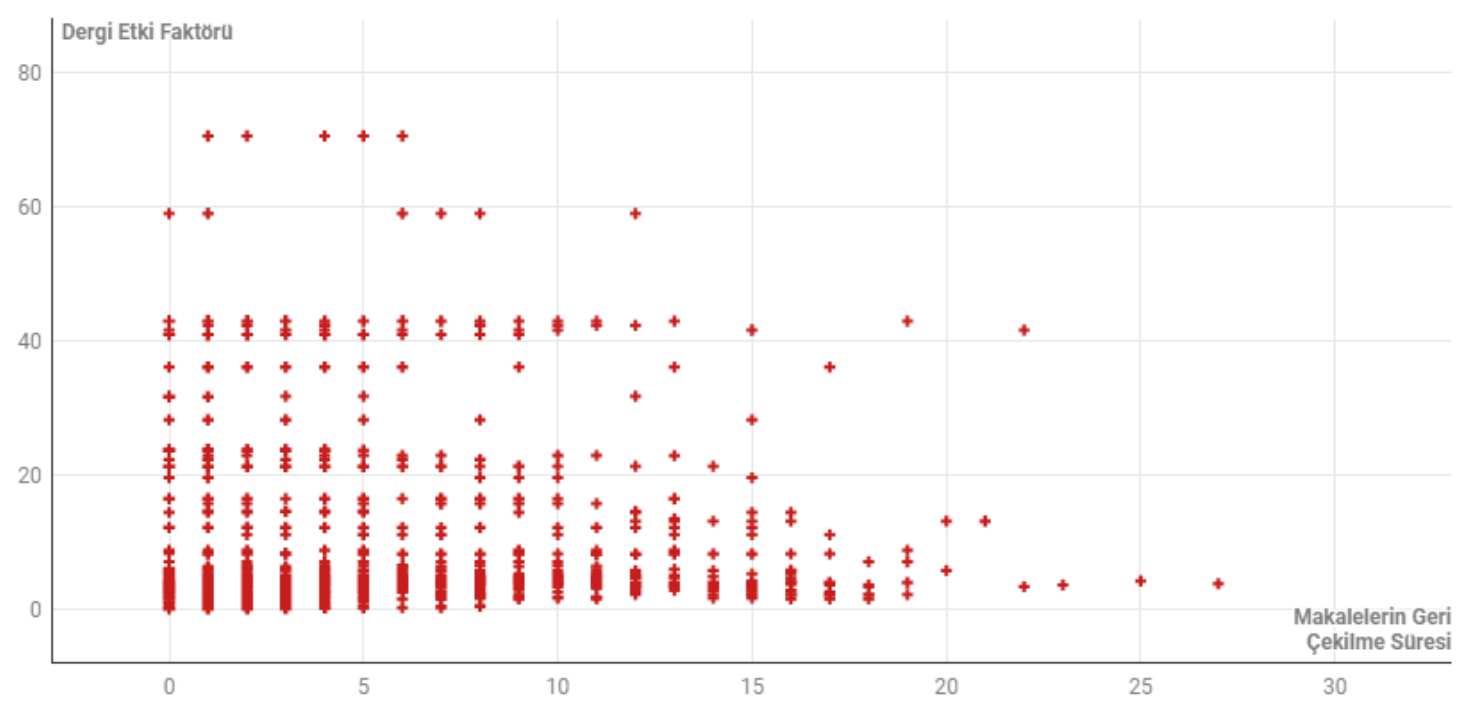

Şekil 4. Dergi etki faktörü ve makalelerin geri çekilme süresi arasındaki ilişki

İki değişken arasındaki ilişkiyi daha detaylı incelemek adına etki faktörü yüksek on beş farklı derginin geri çekilme sürelerine bakılmıştır (bkz. Tablo 4). Bu dergilerin seçiminde çeyrek dilim de etkili olmuştur. Makalelerin \%63'ünün geri çekilme süresi 0-5 yıl aralığındadır. $\mathrm{Bu}$ aralıkta en fazla geri çekilme PNAS, Nature ve Science dergilerinde olmuştur. Bu dergilerin çalışma alanı çok disiplinli bilimleri içermektedir. Popüler ve prestijli olan bu dergilerin, geri çekilme süresinin kısa olması görünürlüğü ve atıf sayıları ile ilişkilendirilebilir. Çalışmamıza benzer bir araştırmada yüksek etki faktörüne sahip dergilerin geri çekilme süresinin kısa olduğu ifade edilmiştir (Steen ve diğerleri, 2013, s. 1). Makalelerin çoğunluğunda (\%78) geri çekilme süresi altı ve daha üstü yıllarda düşüktür. Cancer Research ve Circulation Research dergilerinde bu durum farkl1l1k göstermektedir. Cancer Research dergisinde yayımlanan 26 makale, 6-11 yıl geçtikten sonra geri çekilmiştir. Buna ek olarak 20 makalenin geri çekilme süresi 12-17 yılları arasında değişiklik göstermiştir. Derginin konu alanı ile ilişki kurulduğunda geri çekilme süresinin uzun yıllar sonra gerçekleşmesi, bilimsel bilgi için tehlike oluşturmaktadır. Konu alanı onkoloji olan bu dergideki makalelerin geri çekilme nedenlerine bakılmıştır. Geri çekilen 58 makale intihal, hatalı veri, bilimsel sahtekârlık gibi etik dışı sebeplerden geri çekilmiştir. Yüksek etki faktörüne sahip bu derginin geri çekilme süresinin geç olması şaşırtıcıdır. Söz konusu sürenin derginin geri çekme politikası, editörlerin ve hakemlerin makaleleri değerlendirmedeki etkileri ile ilgili olabileceği düşünülmektedir. İncelenen bu dergilerin makaleleri geri çekme süresi, 0-5 yıl aralığında yoğunlaşmış olması olumlu gözükse de COPE'un yönergesine göre sorun teşkil etmektedir. 


\section{Tablo 4}

Etki faktörü yüksek dergiler ve geri çekilme süreleri

\begin{tabular}{|c|c|c|c|c|c|c|c|c|c|c|c|c|c|c|}
\hline \multirow[t]{3}{*}{ Dergi Ad 1} & \multirow{3}{*}{$\begin{array}{l}\text { Dergi } \\
\text { Çeyreği }\end{array}$} & \multirow{3}{*}{$\begin{array}{l}\text { Etki } \\
\text { Faktörü }\end{array}$} & \multicolumn{12}{|c|}{ Geri Çekilme Süresi (yıl) } \\
\hline & & & \multicolumn{2}{|c|}{$0-5$} & \multicolumn{2}{|c|}{$6-11$} & \multicolumn{2}{|c|}{$12-17$} & \multicolumn{2}{|c|}{$18-23$} & \multicolumn{2}{|c|}{$24-27$} & \multicolumn{2}{|c|}{ Toplam } \\
\hline & & & $\mathrm{n}$ & $\%$ & $\mathrm{n}$ & $\%$ & $\mathrm{n}$ & $\%$ & $\mathrm{n}$ & $\%$ & $\mathrm{n}$ & $\%$ & $\mathrm{n}$ & $\%$ \\
\hline $\begin{array}{l}\text { New England } \\
\text { Journal of Medicine }\end{array}$ & Q1 & 70,67 & 7 & 0,4 & 4 & 0,2 & 0 & 0,0 & 0 & 0,0 & 0 & 0,0 & 11 & 0,6 \\
\hline Lancet & Q1 & 59,10 & 3 & 0,2 & 4 & 0,3 & 1 & 0,1 & 0 & 0,0 & 0 & 0,0 & 8 & 0,6 \\
\hline Nature & Q1 & 43,07 & 41 & 2,2 & 12 & 0,8 & 1 & 0,1 & 1 & 0,1 & 0 & 0,0 & 55 & 3,2 \\
\hline Science & Q1 & 41,06 & 41 & 2,2 & 4 & 0,4 & 0 & 0,0 & 0 & 0,0 & 0 & 0,0 & 45 & 2,6 \\
\hline Cell & Q1 & 36,21 & 22 & 1,3 & 3 & 0,2 & 2 & 0,2 & 0 & 0,0 & 0 & 0,0 & 27 & 1,7 \\
\hline $\begin{array}{l}\text { Journal of Clinical } \\
\text { Oncology }\end{array}$ & Q1 & 28,34 & 6 & 0,4 & 2 & 0,2 & 1 & 0,1 & 0 & 0,0 & 0 & 0,0 & 9 & 0,7 \\
\hline Circulation & Q1 & 23,05 & 4 & 0,4 & 6 & 0,5 & 0 & 0,0 & 0 & 0,0 & 0 & 0,0 & 10 & 0,9 \\
\hline Cell Metabolism & Q1 & 22,41 & 6 & 0,5 & 4 & 0,2 & 0 & 0,0 & 0 & 0,0 & 0 & 0,0 & 10 & 0,7 \\
\hline Blood & Q1 & 16,60 & 18 & 1,1 & 16 & 1,0 & 2 & 0,1 & 0 & 0,0 & 0 & 0,0 & 36 & 2,2 \\
\hline $\begin{array}{l}\text { Circulation } \\
\text { Research }\end{array}$ & Q1 & 15,86 & 4 & 0,3 & 12 & 0,8 & 0 & 0,0 & 0 & 0,0 & 0 & 0,0 & 16 & 1,1 \\
\hline $\begin{array}{l}\text { Journal of the } \\
\text { American Chemical } \\
\text { Society }\end{array}$ & Q1 & 14,69 & 19 & 1,2 & 0 & 0,0 & 1 & 0,1 & 0 & 0,0 & 0 & 0,0 & 20 & 1,3 \\
\hline Molecular Cell & Q1 & 14,54 & 8 & 0,6 & 1 & 0,1 & 4 & 0,3 & 0 & 0,0 & 0 & 0,0 & 13 & 1,0 \\
\hline $\begin{array}{l}\text { Journal of Clinical } \\
\text { Investigation }\end{array}$ & Q1 & 12,28 & 18 & 1,1 & 8 & 0,5 & 3 & 0,3 & 0 & 0,0 & 0 & 0,0 & 29 & 1,9 \\
\hline PNAS & Q1 & 9,58 & 52 & 2,8 & 12 & 0,8 & 2 & 0,2 & 0 & 0,0 & 0 & 0,0 & 66 & 3,8 \\
\hline Cancer Research & Q1 & 8,37 & 12 & 0,7 & 26 & 1,5 & 20 & 1,2 & 0 & 0,0 & 0 & 0,0 & 58 & 3,4 \\
\hline
\end{tabular}

\section{Geri Çekilen Makalelerin Konu ve Ülke Dağılımı}

Konu dağılımının gösterildiği şekilde "Oncology", "Biochemistry and Molecular Biology", "Science and Technology", "Multidisciplinary Science" ve "Cell Biology" alanlarının öne çıktığı görülmektedir (bkz. Şekil 5). En çok geri çekilme işlemi 1933 makalede \%17,2 ile "Oncology" ve \%16,9 ile "Biochemistry and Molecular Biology" konu alanlarında uygulanmıştır. "Science and Technology" konu alanında \%13,5, "Multidisciplinary Science" alanında \%12,4, "Cell Biology" alanında ise \%7,5 geri çekilmiş makale bulunmaktadır.

Bu alanlarda geri çekilme yüzdesinin yüksek olması çalışma alanın çok hızlı güncellenmesi, yayın görünürlüğü, bir konu alanın birden fazla konu alanı ile ilişkili olması ve yayın sayısındaki artış ile açıklanabilir. Bir makale birden fazla konuya dahil olduğundan bire çoklu ilişki söz konusudur. Dairenin çevresindeki halkalar, ağda merkezlik derecesini temsil etmektedir. Ağda merkezlik derecesi, bir çalışma alanının diğer alanlarla olan bağlantısını vermektedir (Chen, 2005, s. 365-366). Alanlar arası bağlantı ne kadar fazlaysa o alanı temsil eden dairenin çevresindeki sarı halkanın genişliği artmaktadır. Ağda merkezlik derecesi konu sıklığından bağımsız olarak değişebilmektedir. 


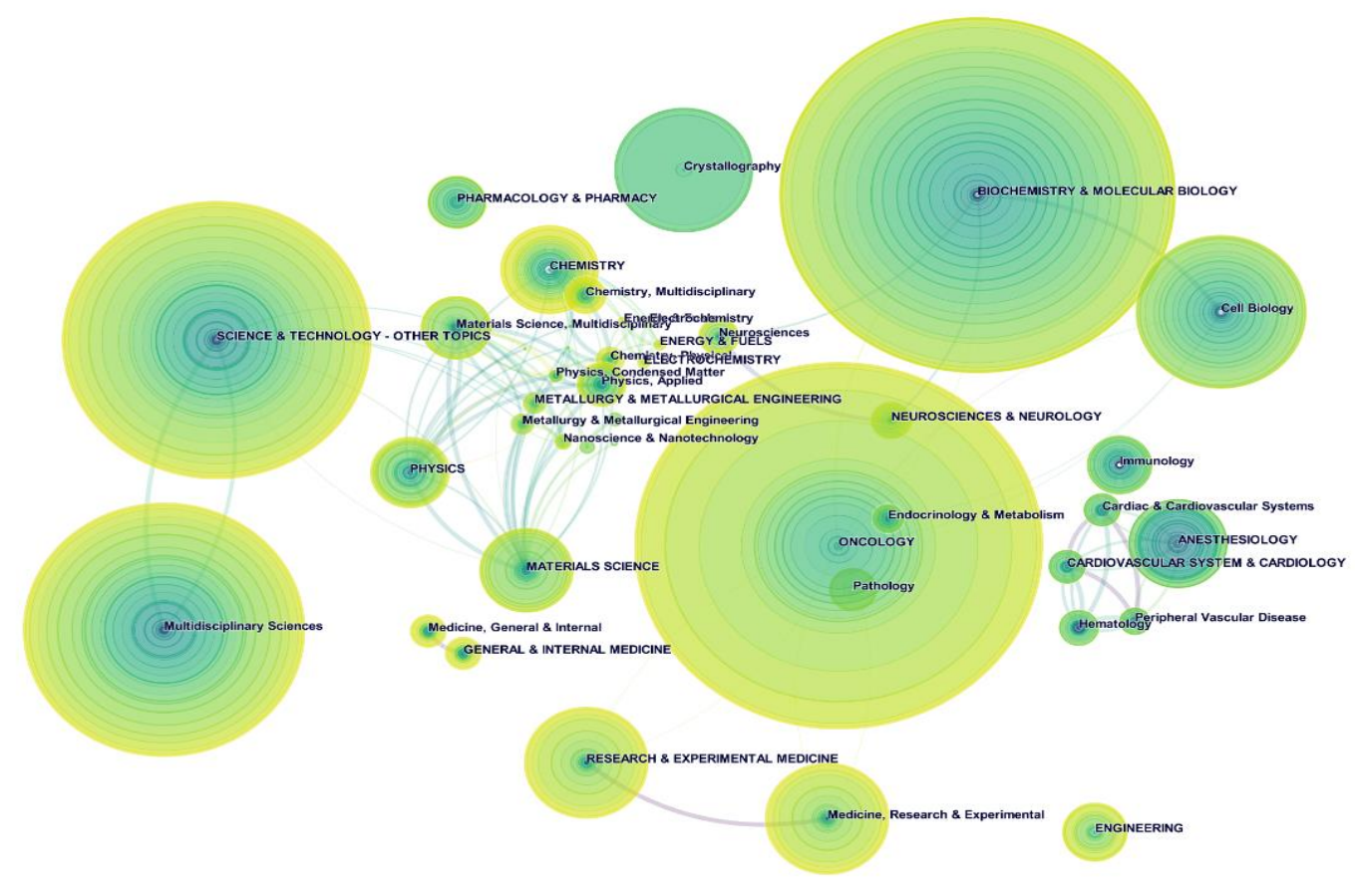

Şekil 5. Konu sıkılığı ve bağlantıları

Elde edilen görselde, en fazla çalışması olan "Oncology" konu alanının diğer konu alanları ile bağlantılı olduğu görülmektedir. Dairelerin içerisinde yer alan renkli katmanlar yılları temsil etmektedir. Merkezdeki koyu renk konu alanındaki yapılan çalışmanın en eski tarihini, en açık renk ise en yeni tarihini ifade etmektedir. Görsel, geri çekilen makalelerin en fazla olduğu konu alanlarında ("Oncology", "Biochemistry and Molecular Biology”, "Science and Technology", "Multidisciplinary Science" ve "Cell Biology") her yıl düzenli olarak çalışmalar yapıldığını göstermektedir. Daireler arası bağlantıların renkleri yılları, bağlantıların kalınlıkları ise bağlantı sıklığını belirtmektedir. En çok çalışmanın yapıldığı "Oncology" ve "Biochemistry and Molecular Biology" alanları birden fazla konu alanın ortak paydası olup, geri çekilen makale sayısının fazla olduğu alanları ifade etmektedir. Özellikle tıp alanının ve alt alanlarının öne çıkması insan yaşamı ile ilişkilendirildiğinde ciddi problemler oluşturabilir. Hatalı veriler, duplikasyon ya da intihal içeren makalelerin, yayımlanması ve geri çekilmesi arasındaki süre uzayabilmektedir. Makale içeriğinin yanlış bilgi içermesi ve geri çekilme süresinin uzaması arasındaki bağlantı, öne çıkan konu alanlarında insan hayatını etkileyen durumların olabileceğini ifade etmektedir. Söz konusu çalışmalardan yararlanan araştırmacıların geri çekme bildirimlerinden haberdar olmadığ durumlarda yeni sorunlar ortaya çıkabilir.

Çalışmada analiz edilen bir diğer konu da geri çekilen makalelerin en fazla hangi ülkede ya da ülkelerde yer aldığıdır. Şekil 6' da geri çekilen makalelerin çalışıldığı ülkelerin ağ haritası gösterilmektedir. Veriler, bir ülkenin minimum doküman sayısı "1" ve bir ülkenin minimum alıntılanma sayısı " 0 ” seçilerek görselleştirilmiştir. Toplamda 73 ülke analiz edilmiştir. Elde edilen harita incelendiğinde, ülkelerin çoğunlukla birbiri ile yakın ilişkiler içinde olduğu ve farklı renklerde birden fazla kümelerin bulunduğu görülmektedir. Haritada Amerika Birleşik Devletleri (ABD) \%34 'lük oran ile geri çekilen makale sayısında ilk sıradadır. Diğer kümelere 
bakıldığında ikinci sırada Çin (\%29), üçüncü sırada Japonya (\%10), dördüncü sırada ise Almanya (\%6) yer almaktadır. Ülkelerin yoğunluk haritasında ABD ve Çin merkezi konumda bulunmaktadır. Bu durum en çok yayın yapan, en çok geri çekilmiş makalesi bulunan ve en fazla ortak yazarlı çalışmaya sahip iki ülke olduklarını göstermektedir. Literatürde bu ülkelerin geri çekilme sayılarının yüksek olması, hataların tekrarlanması ve araştırma etiği standartlarının yetersizliği ile bağlantılı olduğu ifade edilmektedir (Grieneisen ve Zhang, 2012, s. 9). Bununla birlikte bu ülkelerin yayın üretimi sayısının yüksek olduğu unutulmamalıdır.

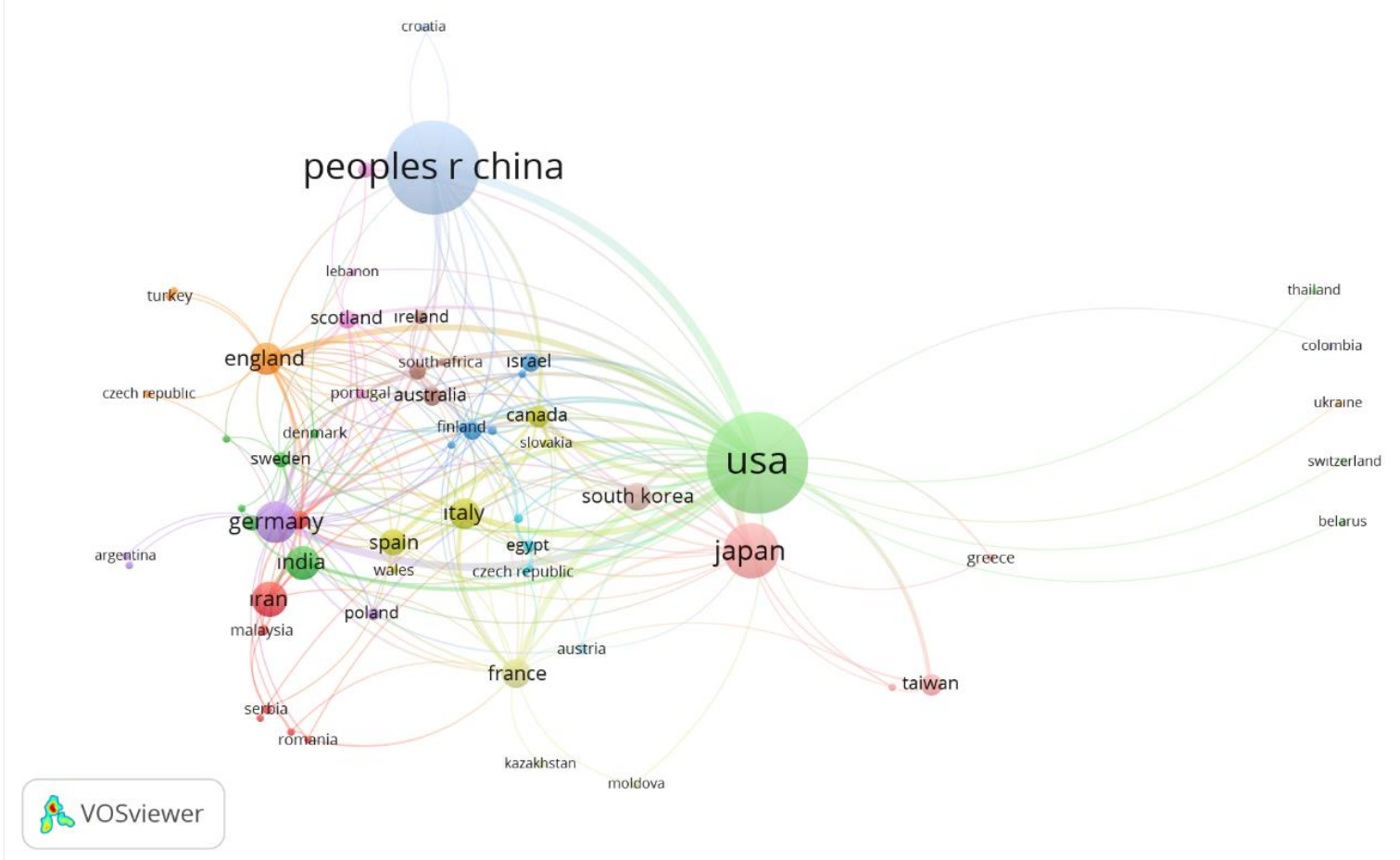

Şekil 6. Geri çekilen makalelerde ülke dağılımı

Görselde dikkat çeken bir diğer ülke İran'dır. Geri çekilen makale oranı \%4’tür. Literatürde yer alan çalışmada, İran adresli geri çekilmiş makalelerin son yıllarda artış gösterdiği belirtilmiştir. İntihal, akran değerlendirmesi ve tekrar eden yayınlar bu makaleleri geri çekilmesindeki en önemli nedenlerdir. Makalelerin \%80'i bilimsel suistimaller nedeniyle geri çekilmiştir (Masoomi ve Amanollahi, 2018, s. 87). Bu çalışma İran'ın geri çekilme sayısında neden artış olduğunu açıklamaktadır. Haritada ülkeler arasındaki bağlantılar mavi çizgiler ile gösterilmektedir. Koyu renkli ve kalın çizgiler iki ülke arasındaki ortak yazarlı çalışmaların yüksek olduğunu ifade etmektedir. Veri kümesi içerisinde diğer ülkeler ile ortak yazarlı çalışması bulunmayan 11 ülke vardır. Türkiye bu haritada oldukça alt sıralarda yer almaktadır. Geri çekilen makale oranı \%0,3 olmakla birlikte, ortak yazarlı çalışma yürüttüğü tek ülke İngiltere'dir. Bu oranın düşük çıkması çalışma kapsamında analiz edilen Türkiye adresli makale sayısının düşük olmasıyla bağlantılıdır. Belirtilen ülkelerin geri çekilmeye yatkın olması yayın sayısı, yayın dili ve çok yazarlı çalışmaları ile ilişkilendirilebilir. Literatürde çalışmamıza benzer bir çalışmada (Amos, 2014, s. 88), geri çekilen makalelerin ülkelere göre dağılımında ABD, Almanya, Japonya ve Çin yine üst sıralarda yer almaktadır. Araştırmada bu ülkeler farklı kategorilerde (bilimsel sahtekârlık, kopyalama, intihal) 
değerlendirilmiştir. Sıralamalar kategorilere göre değişiklik göstermiştir. Bu ülkelerin geri çekilen makale sayısında yoğunluk göstermesi dikkat çekmektedir.

Ülkelerin atıf haritasında, geri çekilen makalelerde en çok atıf alan ülke ABD (46.936 atıf) olmuştur (bkz. Şekil 7). Tüm atıf sayısı içerisinde ABD \%54'lük, Japonya \%11'lik, Çin \%9'luk, İngiltere \%8'lik ve Almanya \%7'lik atıf oranı ile ilk beşte yer almaktadır. Japonya ve Almaya en fazla atıf sayısını 2006 yılı öncesinde alırken, ABD ve İngiltere 2006 ve 2008 yılları arasında almıştır. Ortalama atıf sayısında ise İzlanda (316 ortalama atıf) ilk sırada bulunmaktadır. Buna ek olarak İspanya (121) ve İngiltere (110) ortalama atıf sayısı yüksek ülkelerdir. Ülkelerin atıf sayısının yüksek olması, makalelerin geri çekildikten sonra da atıf almaya devam etmeleri ile açıklanabilir. ABD'nin en çok atıf alan ülke olması yayın dili ve makale sayısı ile ilişkilidir.

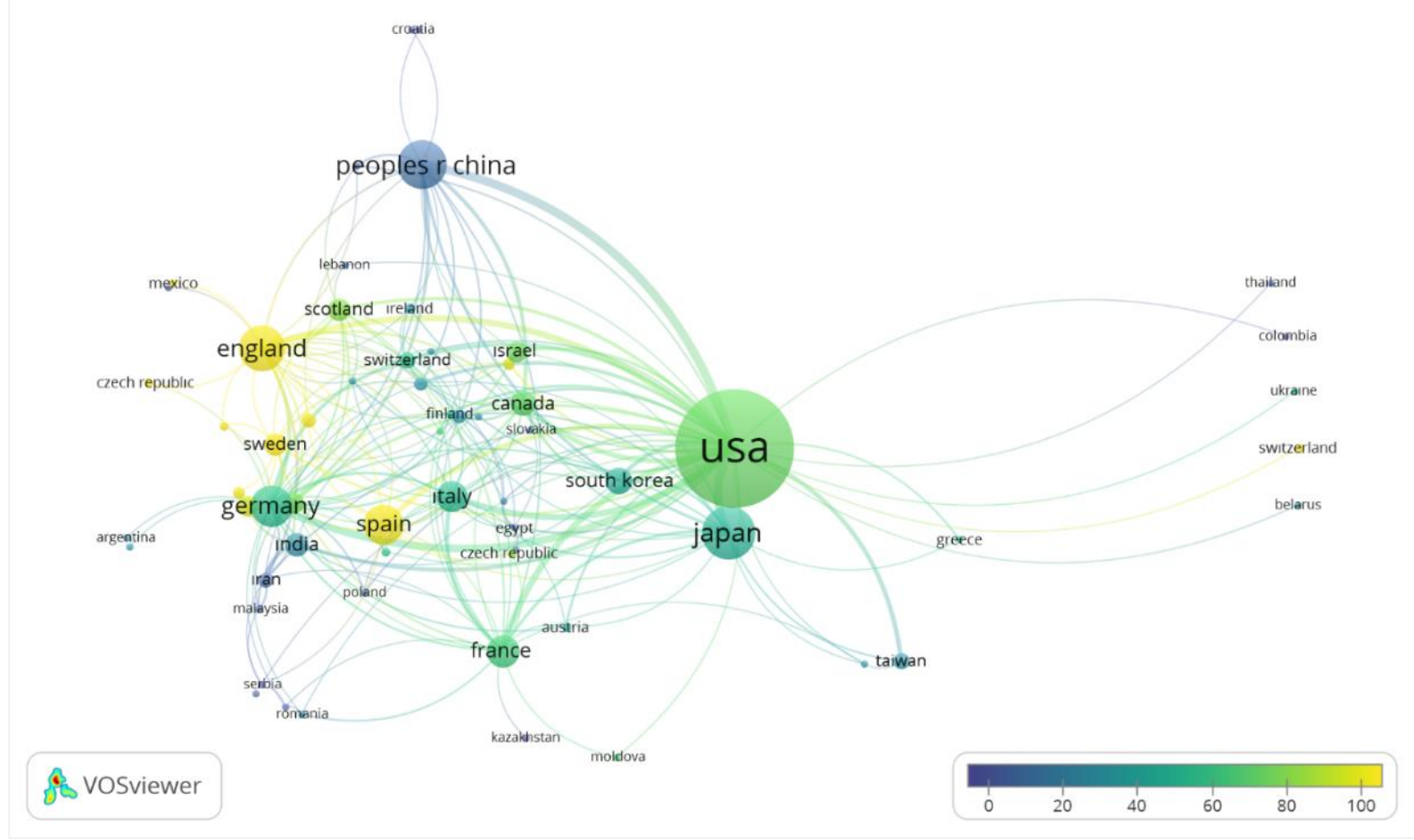

Şekil 7. Ülkelerin atıf ortalaması

\section{Sonuç ve Öneriler}

$\mathrm{Bu}$ çalışmada bilim etiğini ihlal eden geri çekilmiş makaleler farklı değişkenler üzerinden incelenmiştir. Analiz sonucunda geri çekilen makalelerde son y1llarda artış olduğu tespit edilmiştir. En çok geri çekilme \%12'lik oranla 2017 y1lında olmuştur. Geri çekilen makale sayısındaki bu artışın; literatür büyümesiyle, konuyla alakalı farkındalığın artmasıyla, kusurlu makalelerin daha çabuk tespit edilmesiyle ilişkili olduğu düşünülmektedir. Ayrıca açık erişimli dergilerin hızla çoğalması bu yayınları görünür kılarken; Retraction Watch, PubPeer ve PubMed Commons gibi araçların konuyla ilgili araştırmaları açık ve şeffaf bir şekilde tartışmaya sunması sözü edilen yayınlara yönelik bilincin artmasında etkilidir (Teixeira da Silva, 2015, s. 299). Söz konusu makalelerin çoğunluğu $(\% 19,5)$ yayımlandıktan bir yıl sonra geri çekilmektedir. Makalelerin geri çekilmesi kimi zaman araştırmacıların geri bildirimi ile başlamaktadır. Araştırmacıların akademik yayınlara bu duyarlılıkta yaklaşması, bilimsel 
iletişimin sağlıklı bir şekilde yürütülebilmesini sağlayacak ve hatalı yayınların yayımlandıkları yıl ve geri çekildikleri yıl arasındaki sürenin azalmasına olanak tanıyacaktır. Akran değerlendirmesi editörler tarafından teşvik edilmeli ve mevcut durumu iyileştirmek, güçlendirmek için bilimsel iletişism sistemi içindeki tüm katılımcılar sürecin bir parçası olarak kabul edilmelidir.

Dergi niteliğini ve kalitesini etkileyen en önemli yapılardan iki tanesi dergi çeyreği ve etki faktörüdür. Çalışmada bu iki birim üzerinden analizler yapılmıştır. İncelemeler sonucu Q1 çeyreğindeki dergilerde geri çekilen makale sayısının yüksek olduğu tespit edilmiştir. Bu dergi çeyreğinde en fazla geri çekilmeye sahip dergi PNAS $(\% 7,8)$ olmuştur. Tüm dergi çeyrekleri içerisinde en fazla geri çekilme oran $1 \% 7$ ile Tumor Biology dergisine aittir. The New England Journal of Medicine adlı dergide yayımlanan makaleler \%3 ile en çok atıf oranına sahiptir. Dergi etki faktörü ve geri çekilme süresi arasındaki ilişkinin istatiksel açıdan anlamlı olduğu tespit edilmiştir. Dergilerin \%25'inde etki faktörü değeri ve geri çekilme süresi arasında doğrusal bir ilişki olduğu söylenebilir. Etki faktörü yüksek dergilerde geri çekilme süresi maksimum beş yıldır. Bu sonuç, etki faktörü yüksek dergilerin hatalı makaleleri tespit etmede çabuk olduğu göstermekle birlikte, editörlerin bu konuda daha dikkatli olması gerektiğini ifade etmektedir.

Araştırmada tıp alanında ve alt alanlarında geri çekilen makalelerin sayısının yükssek olduğu tespit edilmiştir. Bulgular sonucu "Oncology”, "Biochemistry and Molecular Biology”, "Science and Technology” konu alanları öne çıkmıştır. Bu alanın en önemli özelliği ise uygulamalı bir bilim olması ve insan hayatını yakından ilgilendirmesidir. Özellikle bu disiplinde yapılan yayınların, geri çekilmesinin altında yatan sebepler ciddi problemler oluşturabilir. Aynı zamanda tıp alanında üretilen makalelerin geri çekilme eğilimine yatkın olması; alanın hızlı güncellenmesi, görünür olması ve araştırmacıların yoğun kaynak kullanımı ile açıklanabilir. Bu bilim dalında çalışan araştırmacıların çalışmalarını büyük bir özveri ile yapması gerekmektedir. Bilimsel bilginin üretimi sürecinde etik değerleri ihlal edilecek davranışlardan kaçınılmalıdır.

Geri çekilen makalelerin ülkelere göre dağılımında ABD \%34, Çin \%29, Japonya \%10 ve Almanya \%6 ile ilk sıralarda yer almaktadır. Bu ülkelerin ortak yazarlı çalışma ağı yoğunluğu da yüksektir. Ülkelerin atıf haritasında ABD tüm atıf sayısının \%54'ünü kapsamaktadır. Japonya, Çin, İngiltere ve Almanya atıf sayısında ABD’yi takip eden ülkeler olmuştur. Ülkelerin en çok atıf aldığı yıllar değişiklik göstermektedir. ABD'nin atıf sayısı 2006 ve 2008 yılları arasında yoğunluk göstermektedir. ABD'nin en çok atıf alan ülke olmasının yayın dili ve makale sayısı ile bağlantılı olduğu düşünülmektedir.

Makalelerin geri çekilmesinin altında çeşitli sebepler vardır. Bunlar intihal, bilimsel sahtekârlık, uydurma veriler ya da hatalar olabilir. Araştırmacıların bilimsel yayın üretimi sürecinde bu davranışlardan kaçınması gerekmektedir. Bir yazar için en ciddi yaptırım çalışmasının geri çekilmesidir. Kimi araştırmacılar için makalelerinin geri çekilmesi, akademik saygınlığını kaybetse de önem arz etmemektedir. Öncelikle en önemli girişim araştırmacıların yayınlarındaki hataları kabul etmesi ve olası durumlarda kendini düzeltmeye gitmesidir. $\mathrm{Bu}$ davranış, bilimin bütünlüğünün korunması adına olumlu bir adım olacaktır. Bu konuda dergilerin, yayıncıların ve editörlerin de önemli bir rolü vardır. Geri çekme politikalarının dergiden dergiye değişmesi, belirli bir standardın olmaması bütünlüğü bozmaktadır. Kimi 
dergiler geri çekme nedenini detaylı bir şekilde açıklarken kimi dergiler sadece geri çekme bildirimini vermektedir. Geri çekme nedeninin detaylı bir şekilde belirtilmediği hatalı yayınların atıf alarak kar topu etkisi yaratacağı düşünülmektedir. Bu durumun önüne geçmek için Yayın Etiği Komitesi tarafindan paylaşılan yönergelerde yer alan kriterlerin tüm bilimsel iletişim üyelerini kapsayacak şekilde standartlaşması gerekmektedir. Farklı alanlarda yüksek etkiye sahip yayıncıların geri çekme bildirimlerini ve politikalarını inceleyen Teixeira da Silva ve Dobránszki (2016), şu önerileri sunmuştur:

"Politikalarda yer alan tanımlamalara yönelik tutarsızlıkları engellemek için yazarlar, okuyucular, editörler, dergiler, yayıncılar ve etik kurumlar da dahil olmak üzere tüm katılımcıların görevlerini açık ve şeffaf bir şekilde sunan tanımlayıcı sistemlerin oluşturulması gerekmektedir. Yayın Etiği Komitesi yönergelerine uymayan üyelerin ihlallerinin nasıl değerlendirileceğini içeren kurallara da ihtiyaç vardır” (s. 552).

Araştırmaların incelenmesi sürecinde editörlerin ve hakemlerin ciddi sorumlulukları vardır. Bir yayının geri çekilmesi kararı da bu sorumluluklar arasındadır. Etik komiteler yayınların hangi durumlarda geri çekileceğine ilişkin tavsiyelerde bulunurken, bu sürecin nasıl gerçekleştirileceği konusunda öneri sunmamaktadır. Bu amaçla yayınların bütünlüğünü değerlendirmek için editörlere ve hakemlere yönelik araç geliştirmek, hakem incelemesini ve editoryal kaliteyi artırmayı sağlayan önemli bir yöntemdir. Grey, Bolland, Avenell, Klein ve Gunsalus (2020, s. 167), editörlere yönelik önemli bir araç geliştirmişlerdir. "Yeniden Düzenlenmiş" kontrol listesinin, hakemlerin ve editörlerin yayınları sistematik bir şekilde değerlendirmesini sağlayacağını, hatalı yayınlara karar vermeyi kolaylaştıracağını düşünmektedirler. Bununla birlikte karar vericilerin yayınları değerlendirmedeki etkilerini ve kalitelerini görmek için hata indeksinin (Margalida ve Colomer, 2015, s. E1511) uygulanması sürece farklı bir bakış açısı sunacaktır. Türkiye'de konuya ilişkin çalışmaların yetersiz olduğu bilinmektedir. Türkiye adresli yayınlar üzerinden yapılacak çalışmaların sonuçları dergilerin, yayıncıların, editörlerin ve akran değerlendirmelerinin farklı bir boyutunu ele alacaktır. Geri çekilen makalelerde uygulanan politikaları, geri çekme sürecini, bilimsel iletişimin tüm katılımcılarını değerlendirmek amacıyla daha fazla yayın yapılmalıdır.

\section{Teşekkür}

Çalışmamızın her aşamasında engin bilgilerini paylaşarak katkıda bulunan, öneriler sunan ve desteğini hiç esirgemeyen değerli hocamız Doç. Dr. Yurdagül ÜNAL'a sonsuz teşekkür ederiz.

\section{Kaynakça}

Ajiferuke, I. ve Adekannbi, J.O.(2020). Correction and retraction practices in library and information science journals. Journal of Librarianship and Information Science, 52(1), 169-183. doi: 10.1177/0961000618785408

Al, U. ve Soydal, İ. (2015). Bilimsel iletişimin farklı bir yüzü: Geri çekilen makaleler. U. Al ve Z. Taşkın (Yay. haz.). Prof. Dr. Irfan Çakın'a armağan içinde (s. 22-37). Ankara: Hacettepe Üniversitesi Bilgi ve Belge Yönetimi Bölümü. Erişim adresi: http://yunus.hacettepe.edu.tr/ umutal/publications/retraction.pdf

Alrawadieh, Z. ve Zareer, A. (2019). Exploring Retraction in Tourism and Hospitality Journals. European Journal of Tourism Research,22, 20-30. Erişim Adresi: https://ejtr.vumk.eu/index.php/about/article/view/372 
Amos, K.A.(2014). The ethics of scholarly publishing: exploring differences in plagiarism and duplicate publication across nations. Journal of the Medical Library Association, 102(2), 87-91. doi: 10.3163/1536-5050.102.2.005

Campos-Varela, I., Villaverde-Castañeda, R. ve Ruano-Raviña, A. (2020). Retraction of publications: A study of biomedical journals retracting publications based on impact factor and journal category. Gaceta Sanitaria, 34(5), 1-5. doi: 10.1016/j.gaceta.2019.05.008

Chen, C., Hu, Z., Milbank, J. ve Schultz, T. (2012). A visual analytic study of retracted articles in scientific literature. Journal of the American Society for Information Science and Technology, 64(2), 234-253. doi: 10.1002/asi.22755

Chen, C. (2005). CiteSpace II: Detecting and visualizing emerging trends and transient patterns in scientific literature. Journal of the American Society for information Science and Technology, 57(3), 359-377. doi: 10.1002/asi.20317

Committee on Publication Ethics (2019). Guidelines: Retraction guidelines. Erişim adresi: https://publicationethics.org/files/retraction-guidelines.pdf

Damineni, R.S., Sardiwal, K.K., Waghle, S.R. ve Dakshyani, M.B. (2015). A comprehensive comparative analysis of articles retracted in 2012 and 2013 from the scholarly literature. Journal of International Society Preventive and Community Dentistry, 5(1), 19-23. Erişim adresi: https://search.proquest.com/docview/1732325719/fulltextPDF/3598BE4DE7E14614PQ/1?acco untid $=11248$

Dinh, L., Sarol, J., Cheng, Y.Y., Hsiao, T.K., Parulian, N. ve Schneider, J. (2019). Systematic examination of pre- and post-retraction citations. Proceedings of the Association for Information Science and Technology, 56, 390-394. doi: 10.1002/pra2.35

Fanelli, D. (2013). Why growing retractions are (mostly) a good sign. PLOS Medicine, 10(12), 1-6. doi: 10.1371/journal.pmed.1001563

Fang, F.C. ve Casadevall, A. (2011). Retracted science and the retraction index. Infection and Immunity, 79(10), 3855-3859. doi: 10.1128/IAI.05661-11

Fang, F.C., Steen, R.G. ve Casadevall, A. (2012). Misconduct accounts for the majority of retracted scientific publications. Proceedings of the National Academy of Sciences, 109(42), 1702817033. doi: 10.1073/pnas.1212247109

Foo, J.Y.A. (2010). A retrospective analysis of the trend of retracted publications in the field of biomedical and life sciences. Science and Engineering Ethics, 17(3), 459-468. doi: 10.1007\%2Fs11948-010-9212-8

Grey, A., Bolland, M.J., Avenell, A., Klein, A.A. ve Gunsalus, C.K. (2020). Check for publication integrity before misconduct. Nature, 577, 167-169. doi: 10.1038/d41586-019-03959-6

Grieneisen, M.L. ve Zhang, M. (2012). A comprehensive survey of retracted articles from the scholarly literature. PLOS ONE, 7(10), 1-15. doi: 10.1371/journal.pone.0044118

Gutiérrez, S.A., Barbosa, H.J., Cuero, M.S., Duarte, E.J, Gaitán, F.E., Lozano, J.L.,... Vallejo, G.A. (2016). La retractación y la corrección de la literatura científica para conservar la integridad y la confianza en la ciencia: Un análisis de retractaciones de publicaciones biomédicas de libre acceso en PubMed, 1959-2015. Revista de la Academia Colombiana de Ciencias Exactas, Físicas y Naturales, 40(157), 568-579. doi: 10.18257/raccefyn.399 
Hermerén, G. (2008). Integridad y mala conducta en el ámbito investigador. Sociedad Española de Bioquímica $y$ Biología Molecular, 156, 5-10. Erişim adresi: https://www.sebbm.es/revista/repositorio/pdf/156/d01156.pdf

Margalida, A. ve Colomer, M.À. (2015). Mistake index as a surrogate of quality in scientific manuscripts. Proceedings of the National Academy of Sciences, 112(13), E1511. doi: 10.1073/pnas.1500322112

Masoomi, R. ve Amanollahi, A. (2018). Why Iranian biomedical articles are retracted? The Journal of Medical Education and Development, 13(2), 87-100. Erişim adresi: http://jmed.ssu.ac.ir/article1-885-en.html

Pajić, D. (2015). On the stability of citation-based journal rankings. Journal of Informetrics, 9(4), 9901006. doi: 10.1016/j.joi.2015.08.005

Steen, R.G., Casadevall, A. ve Fang, F.C. (2013). Why has the number of scientific retractions increased? PLOS ONE, 8(7), 1-9. $\quad$ Erişim adresi: https://www.ncbi.nlm.nih.gov/pmc/articles/PMC3704583/pdf/pone.0068397.pdf

Stretton, S., Bramich, N.J., Keys, J.R., Monk, J.A., Ely, J.A., Haley, C.,... Woolley, K.L. (2012). Publication misconduct and plagiarism retractions: A systematic, retrospective study. Current Medical Research and Opinion, 28(10), 1575-1583. doi: 10.1185/03007995.2012.728131

Teixeira da Silva, J.A. (2015). The importance of retractions and the need to correct the downstream literature. Journal of Scientific Exploration, 29(2), 299-302. Erişim adresi: https://www.scientificexploration.org/docs/29/jse_29_2_TeixeiradaSilva.pdf

Teixeira da Silva, J.A. ve Dobránszki, J. (2016). Notices and policies for retractions, expressions of concern, errata and corrigenda: Their importance, content, and context. Science and Engineering Ethics, 23(2), 521-554. doi: 10.1007/s11948-016-9769-y

Wager, E., Barbour, V., Yentis, S. ve Kleinert, S. (2009). Retractions: Guidance from the Committee on Publication Ethics (COPE). Maturitas, 64(4), 201-203. doi: 10.1016/j.maturitas.2009.09.018

Wang, J., Ku, J.C., Alotaibi, N.M. ve Rutka, J.T. (2017). Retraction of neurosurgical publications: A systematic review. World Neurosurgery, 103, 809-814. doi: 10.1016/j.wneu.2017.04.014 